\title{
Study on Coriander (Coriandarum sativum L.) Based Intercropping System for Enhancing System Productivity
}

\author{
Vinod Kumar*, R.S. Mehta, S.S. Meena, Mahendra Parsoya, \\ Rajveer and Chokh Nath Sidh
}

ICAR-National Research Center on Seed Spieces, Ajmer-305206, Rajasthan, India

*Corresponding author

\section{A B S T R A C T}

Keywords

Coriander, Intercropping, Net returns, LER, Yield

Article Info

Accepted:

26 May 2018

Available Online:

10 June 2018
A field experiment comprising ten treatments of intercropping systems replicated four times was conducted in Randomized Block Design with during rabi season, 2016-17. Results indicated that sole coriander exhibited the higher plant height and number of branches per plant $60 \mathrm{DAS}, 90 \mathrm{DAS}$ and at harvest as compared to different intercropping system. Further, results showed that sole coriander exhibited significantly highest values of yield attributes viz., number of umbels per plant, number of umbellate per umbel, seeds per umbellate, 1000 - seed weight, seed yield per plant and seed yield per hectare as compared to different intercropping system. Sole French radish, sole Knolkhol and sole fenugreek resulted higher plant population, plant height at harvest, number of leaves per plant, diameter of curd and fresh marketable yield as compared to different intercropping systems. Intercropping of coriander with French radish in 1:1 row ratio resulted significantly higher land equivalent ratio (1.83), coriander equivalent yield (4272 kg/ha), gross return (Rs.341728/- ha), net return (Rs.283228/- ha) and BCR (4.84)followed by intercropping of coriander with French radish in 2:2 paired row ratio. Intercropping of coriander with fenugreek in 1:1 and 2:2 recorded significantly higher $\mathrm{N}, \mathrm{P}$, and $\mathrm{K}$ availability in soil after harvest of crop. Thus, it is inferred that intercropping of intercropping of coriander with French radish in 1:1 row ratio is better for realizing higher system productivity and economic returns.

\section{Introduction}

India is the world's largest producers, consumers and exporter of seed spices. Coriander (Coriander sativum) generally called as "Dhania" belongs to the Apiaceae family. It is mainly grown in Rajasthan, Gujarat, Madhya Pradesh, Tamilnadu and Uttar Pradesh. Coriander is an important seed spice crop of Rajasthan which is mostly grown in Kota, Bundi, Jhalawar and Baran. Area, production and productivity of coriander in Rajasthan are 2.48 lakh hectares, 1.98 lakh M tonnes and productivity of $680 \mathrm{~kg} / \mathrm{ha}$, respectively (Anon - 2015). Ahlawat and Gangaiah (2010) reported higher system productivity in chickpea intercropped with linseed over sole chickpea. Mustard and 
chickpea intercropping have exhibited higher land equivalent ratio (1.41) over in sole crops (Thomas et al., 2010). Shortages of vegetables in the country have focused the attention on intercropping systems which have capacity to improve the physical, biological and chemical properties of soil (Mehta et al. 2010). Thus, productivity of system can be enhanced with change in crop configuration for inclusion of other crops in the existing cropping system. Hence the study on effect of coriander based inter-cropping system with vegetable crops was undertaken with an objective to find most efficient inter cropping system for realizing higher system productivity.

\section{Materials and Methods}

The experiment was laid out at Research farm of ICAR-National Research Center on Seed Spices, Ajmer, Rajasthan, during 'Rabi' season of 2016-17. The soil of research farm is sandy loam, poor in fertility and water

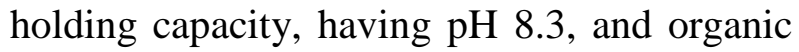
carbon $0.23 \%$, available $\mathrm{N} 68.49 \mathrm{~kg} / \mathrm{ha}, \mathrm{P}_{2} \mathrm{O}_{5}$ $7.05 \mathrm{~kg} / \mathrm{ha}, \mathrm{K}_{2} \mathrm{O} 230.16 \mathrm{~kg} / \mathrm{ha}$. The experiment comprising of 10 treatments viz., sole coriander, sole French radish, sole knolkhol, sole fenugreek, coriander intercropping with French radish, knolkhol and fenugreek in 1:1 and 2:2 row rati was laid in randomized block design with four replications. As per technical programme one row of radish, knolkhol and fenugreek was added between two rows of coriander in 1:1 intercropping ratio and two rows of vegetable crops were added in a pair of two rows of coriander (paired row having $25 / 35 \mathrm{~cm}$ ). A uniform recommended doses of $60 \mathrm{Kg} \mathrm{N}$ and $40 \mathrm{~kg} \mathrm{P}_{2} \mathrm{O}^{5} \mathrm{ha}^{-1}$ and $30 \mathrm{~kg} \mathrm{~K}_{2} \mathrm{O}$ for sole coriander, $120 \mathrm{~kg} \mathrm{~N}, 60 \mathrm{~kg} \mathrm{P}_{2} \mathrm{O}_{5}$ and 40 $\mathrm{kg} \mathrm{K}_{2} \mathrm{O}$ for sole knolkhol, $100 \mathrm{~kg} \mathrm{~N}, 50 \mathrm{~kg}$ $\mathrm{P} 2 \mathrm{P} \mathrm{O} 5$ and $40 \mathrm{~kg} \mathrm{~K} 2 \mathrm{O}$ for french radish and $20 \mathrm{~kg} \mathrm{~N}, 40 \mathrm{~kg}$ P2O5 and $30 \mathrm{~kg} \mathrm{~K} 2 \mathrm{O}$ for fenugreek was applied. In intercropping of coriander and vegetables $100 \%$ NPK of sole coriander and $50 \%$ NPK of respective vegetables were applied. 1/3 $\mathrm{N}$ and full dose of phosphorus and potash were applied at the time of sowing and remaining $2 / 3 \mathrm{~N}$ was applied with low pressure drip irrigation through urea at an interval of 8 days. The standard agronomic practices were applied for raising healthy coriander crop as well as French radish, knolkhol and fenugreek. Immediately after sowing irrigation was provided with low pressure drip irrigation having normal operating pressure of $0.1 \mathrm{~kg} \mathrm{sq}$ $\mathrm{cm}-1$. Each plot has 5 lateral lines of drip, the drippers were fitted on lateral lines at the distance of $30 \mathrm{~cm}$. Each dripper had discharge rate of 1.25 litter /hour. First irrigation was given just after sowing and subsequent irrigations were provided at four days interval based on $80 \mathrm{CPE}$. Total 25 irrigations, each four days interval were given to crop starting from sowing to 15 days before harvesting. Yield of component crop was calculated based on proportionate area occupied by them. The yield of coriander, French radish, knolkhol and fenugreek was converted into coriander equivalent yield as per prevailing rates in market and treatment evaluation was done accordingly. Economic analysis of the different treatment was done for drawing conclusion.

\section{Results and Discussion}

Growth, yield parameters and yield of coriander

Significantly higher plant heights, number of branches /plant at maturity of coriander were recorded in sole coriander over all intercropping systems (Table 1). In respect to intercropping systems, significantly higher growth parameters of coriander were recorded with 1:1 intercropping ratio of coriander and component crops viz. French radish, knolkhol and fenugreek. The higher plant height in sole coriander in 1:1 intercropping ratio was on account of less competition for sunlight, 
space, nutrient and water as compared to other ratio. Tiwari et al. (2002) reported depressing effect on growth and performance of fennel when intercropped with vegetable crop. Similarly Nandekar et al.(1995) reported decrease in growth parameters of potato with intercropping.

The higher yield attributes and yield of coriander with French radish, knolkhol and fenugreek intercrops was recorded in 1:1 ratio. Intercropping of coriander with French radish resulted in significantly higher yield and yield attributes of coriander over khnolkhol and fenugreek inter- cropping (Table 2).The higher yield attributes and yield of coriander in 1:1 ratio with all intercrops might be due to less competition for space, sunlight, water and nutrients between coriander and component crops which gave higher growth parameters resulting in higher translocation of photosynthates from source to sink resulting in higher yield and yield attributes of coriander. Tiwari et al. (2002) reported depressing effect on growth and performance of fennel when intercropped with vegetable crop. Similarly
Nandekar et al. (1995) reported decrease in yield of potato with intercropping.

\section{Yields attributes and yield of intercrops}

Yield attributes and yield of intercrops recorded was higher in respective sole crops as compared to intercropping with coriander. Further, perusal of data in Table 2 and3 revealed that among different inter cropping ratios, the higher yield and yield attributes of intercrops was exhibited in 1:1 ratio. Intercropping of coriander + French radish in all the ratios resulted higher economic yield of French radish as compared to knolkhol and fenugreek. The higher yield of all the intercrops crops in 1:1 ratio was on account of higher plant population due to accommodation of more number of rows in between interspaces as compared to 2:2 ratio. Mehta et.al.(2012 and 2015) also reported higher yield attributes of intercrops and inter crop in $1: 1$ intercropping ratio over 2:2and 1:2 intercropping ratio.

Table.1 Effect of intercropping system on growth and yield attributes of coriander at harvest

\begin{tabular}{|c|c|c|c|c|c|c|c|}
\hline Treatment & $\begin{array}{l}\text { Plant } \\
\text { Height } \\
(\mathrm{cm})\end{array}$ & $\begin{array}{l}\text { Branches/ } \\
\text { plant }\end{array}$ & $\begin{array}{c}\text { Umbels/ } \\
\text { plant }\end{array}$ & $\begin{array}{c}\text { Umbellate/ } \\
\text { umbel }\end{array}$ & $\begin{array}{l}\text { Seeds/ } \\
\text { umbellate }\end{array}$ & $\begin{array}{l}1,000 \text { seed } \\
\text { weight } \\
\text { (g) }\end{array}$ & $\begin{array}{l}\text { Seed } \\
\text { yield/ } \\
\text { plant }(g)\end{array}$ \\
\hline Sole Coriander & 107.66 & 16.70 & 24.15 & 15.35 & 18.25 & 10.38 & 8.39 \\
\hline Sole French redish & - & - & - & - & - & - & - \\
\hline Sole knolkhol & - & - & - & - & - & - & - \\
\hline Sole fenugreek & - & - & - & - & - & - & - \\
\hline Coriander + French radish $1: 1$ & 104.34 & 15.80 & 23.70 & 15.20 & 17.95 & 10.25 & 7.54 \\
\hline Coriander + French radish $2: 2$ & 102.19 & 15.45 & 23.50 & 15.00 & 17.85 & 10.18 & 6.94 \\
\hline Coriander + knolkhol 1:1 & 103.96 & 15.75 & 23.60 & 14.20 & 17.95 & 10.23 & 7.48 \\
\hline Coriander + knolkhol 2:2 & 102.1 & 15.40 & 23.45 & 14.00 & 17.75 & 10.16 & 6.88 \\
\hline Coriander + fenugreek 1:1 & 103.5 & 15.65 & 23.55 & 14.10 & 17.95 & 10.21 & 7.30 \\
\hline Coriander + fenugreek $2: 2$ & 102.0 & 15.15 & 22.85 & 13.95 & 17.85 & 10.13 & 6.71 \\
\hline $\mathrm{SEm}+$ & 2.74 & 0.40 & 0.65 & 0.44 & 0.47 & 0.65 & 0.24 \\
\hline $\mathrm{CD}(\mathrm{P}=0.05)$ & NS & 1.20 & NS & NS & NS & NS & 0.72 \\
\hline
\end{tabular}


Table.2 Effect of different intercropping on growth and yield attributes of component crops

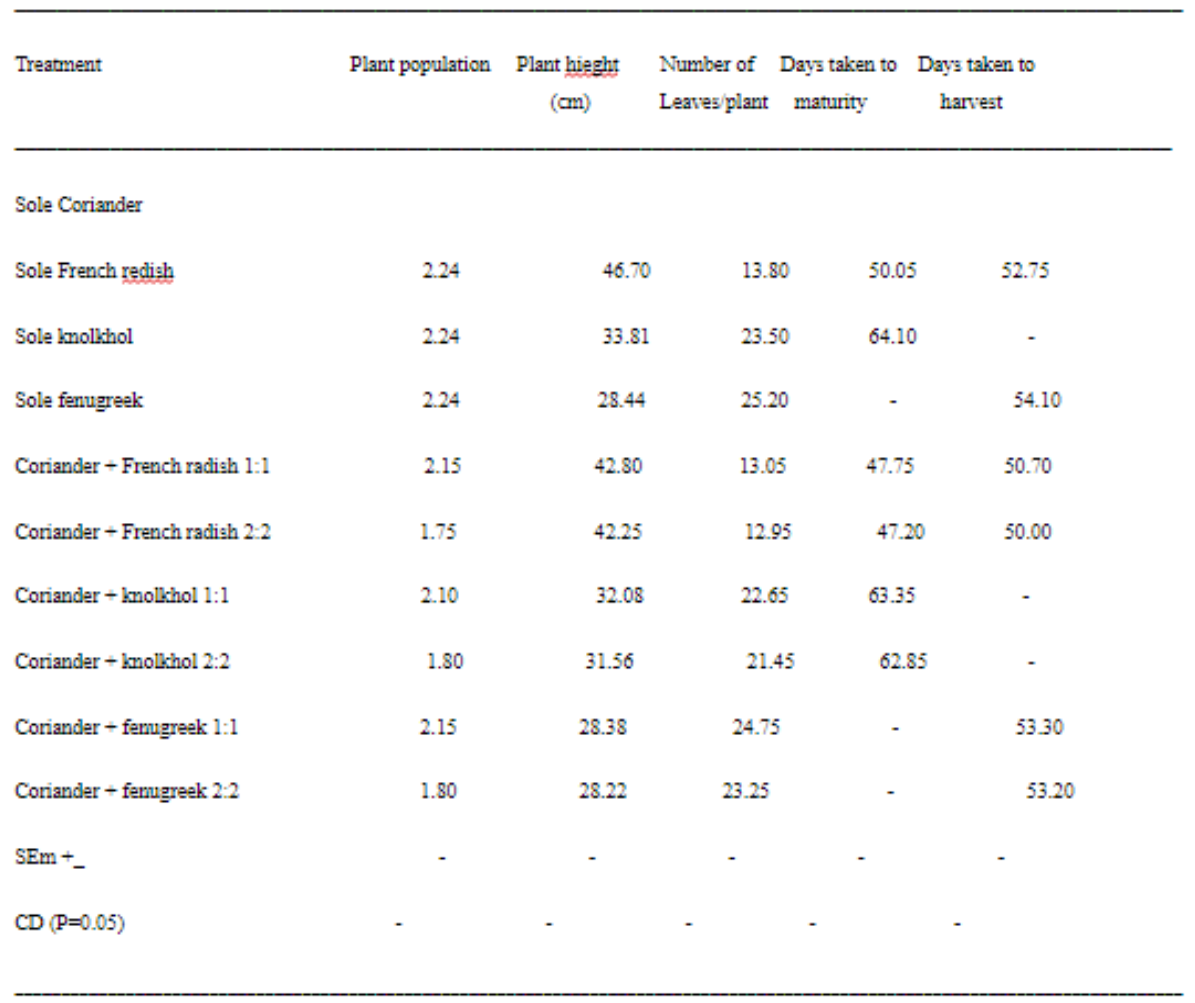

Table.3 Effect of intercropping systems on yield of coriander and component crops and system productivity (coriander equivalent yield)

\begin{tabular}{|c|c|c|c|}
\hline $\begin{array}{l}\text { Treatment } \\
\text { yield }\end{array}$ & $\begin{array}{l}\text { |Seed yield of } \\
\text { Coriander }(q / h a)\end{array}$ & $\begin{array}{l}\text { Seed yield of } \\
\text { intercrops }(q / h a)\end{array}$ & $\begin{array}{c}\text { Coriander equivalent } \\
\qquad(\mathrm{q} / \mathrm{ha})\end{array}$ \\
\hline Sole Coriander & 18.90 & - & 18.90 \\
\hline Sole French redish & - & 273.62 & 27.36 \\
\hline Sole knolkhol & - & 137.22 & 17.15 \\
\hline Sole fenugreek & - & 276.64 & 27.67 \\
\hline Coriander + French radish 1:1 & 16.98 & 257.36 & 42.72 \\
\hline Coriander + French radish 2:2 & 15.60 & 253.72 & 40.98 \\
\hline Coriander + knolkhol 1:1 & 16.83 & 117.75 & 31.56 \\
\hline Coriander + knolkhol $2: 2$ & 15.42 & 113.75 & 29.65 \\
\hline Coriander + fenugreek $1: 1$ & 16.49 & 246.57 & 41.15 \\
\hline Coriander + fenugreek $2: 2$ & 15.10 & 238.28 & 38.94 \\
\hline $\mathrm{SEm}+$ & 0.59 & 7.98 & 1.15 \\
\hline $\mathrm{CD}(\mathrm{P}=0.05)$ & 1.76 & 23.3 & 3.35 \\
\hline
\end{tabular}


Table.4 Effect of intercropping systems on economics and land

\begin{tabular}{|c|c|c|c|c|c|}
\hline Treatment & $\begin{array}{l}\text { Cost of } \\
\text { cultivation } \\
\text { _ }\left(R_{s} / h a\right)\end{array}$ & $\begin{array}{c}\text { Gross } \\
\text { returns } \\
\text { _ RS/ha) }\end{array}$ & $\begin{array}{l}\text { Net returns } \\
(\mathrm{Rs} / \mathrm{ha})\end{array}$ & $B: C$ ratio & LER \\
\hline Sole Coriander & 55300 & 151200 & 95900 & 1.73 & 1.00 \\
\hline Sole French radish & 61750 & 218896 & 157146 & 2.54 & 1.00 \\
\hline Sole knolkhol & 64500 & 137220 & 72720 & 1.12 & 1.00 \\
\hline Sole fenugreek & 66250 & 221312 & 155062 & 2.34 & 1.00 \\
\hline Coriander + French radish 1:1 & 58500 & 341728 & 283228 & 4.84 & 1.83 \\
\hline Coriander + French radieh $2: 2$ & 58500 & 327776 & 269276 & 4.60 & 1.74 \\
\hline Coriander + knolkhol 1:1 & 59700 & 252390 & 192690 & 3.22 & 1.74 \\
\hline Coriander + knolkhol 2:2 & 59700 & 237110 & 267876 & 2.97 & 1.63 \\
\hline Coriander + ferugreek $1: 1$ & 61300 & 329176 & 250124 & 4.36 & 1.76 \\
\hline Coriander - fenugreek 2.2 & 61300 & 311424 & 280376 & 4.08 & 1.65 \\
\hline $\mathrm{SEm}+-$ & - & - & - & - & 0.05 \\
\hline $\mathrm{CD}(\mathrm{P}=0.05)$ & - & - & - & - & 0.15 \\
\hline
\end{tabular}

\section{System productivity}

Significantly higher coriander equivalent yield (CEY) and land equivalent ratio (LER) of the system was re- corded in intercropping as compared to sole cropping (Table 4). Coriander + French radish in all ratios resulted higher CEY and LER as compared to its intercropping with knolkhol and fenugreek. Further analysis showed that 1:1 ratio with all intercrops proved superior resulting in higher CEY and LER over 2:2 ratio. Coriander + French radish in 1:1 ratio exhibited 126 and $83 \%$ higher CEY and LER, respectively over sole coriander. The higher CEY and LER in intercropping system was on account of additional yield of intercrops without much reduction in yield of base crop. The highest CEY and LER in 1:1 ratio with French radish, knolkhol and fenugreek was due to proportionately less reduction in coriander yield as compared with 2:2 ratio resulting in better yield of intercrop. Bhati (1992) reported higher fennel equivalent yield in intercropping as compared to sole crops. Similarly, Ahlawat and Gangaiah (2010) also reported higher system productivity in chickpea intercropped with linseed over sole chickpea. Thomas et al. (2010) reported thehighest LER of 1.41 in mustard and chickpea intercropping over sole crops.Mehta et.al.(2015) also reported higher fennel equivalent yield and LER in intercropping system over sole cropping.

\section{Economics}

Intercropping of coriander + French radish in 1:1 ratio exhibited significantly higher net return (Rs 283228/ha) and B: C ratio (4.84) which was 126 and $83 \%$ higher, respectively over coriander + French radish (2:2). 
Coriander+French radish/knolkhol/fenugreek in 1:1 ratio proved superior which resulted in higher net return and $\mathrm{B}$ : $\mathrm{C}$ ratio over 2:2 ratio. Similar benefits of inter- cropping on economics in fenugreek + mustard was reported by Yadav et al, (2003). Khurana and Bhatia (1995) in intercropping of onion and potato with fennel and Ahlawat and Gangaiah (2010) in chickpea + linseed reported similar results.It is concluded that intercropping of coriander and French radish in 1:1 ratio is promising for higher productivity and profitability.

\section{References}

Ahlawat, I.P.S. and Gangaiah. B. 2010. Effect of land configuration and irrigation on sole and linseed (Linum usitatissimum) intercropped chickpea (Cicer arietinum). Indian Journal of Agricultural Sciences 80(3): 248-249.

Bhati, D.S. 1992. Intercropping in fennel (Foeniculum vulgare). Indian Journal of Agricultural-Sciences62(3): 218219.

Khurana, S.C. and Bhatia, A.K. 1995. Intercropping of onion and fennel with potato. Journal of the Indian Potato Association 22(3-4): 140-145.

Mehta, R.S., Meena, S.S. and Anwer, M.M. 2010. Performance of coriander
(Coriandrumsativum)

based intercropping system. Indian Journal of Agronomy, 55 (4): 286-289.

Nandekar, D.N., Sharma, T.R., Sharma, R.C. 1995. Effect of potato based intercropping system on yield and economics. Journal of the Indian Potato Association 22(3-4): 159-161.

Thomas, A., Sharma, U.C., Thenua, O.V.S. and Shivakumar, B.G.2010. Effect of levels of irrigation and fertility on yield and economics of chickpea (Cicer arietinum) and Indian mustard (Brassica juncea) under sole and intercropping systems Indian Journal of Agricultural Sciences 80(5): 372376.

Tiwari, R.S., Ankur, A, Sengar, S.C. and Agarwal, A. 2002. Effect of intercropping on yield and economics of fennel (Foeniculum vulgare Mill.). Crop Research Hisar23(2):369-374.

Yadav, P.C., Makhan Lal and Agarwal, P. 2003. Intercropping of mustard in fenugreek (Trigonella foenymgraecum L) under varying fertility levels. Journal of Farming System Research\& Development8(1): 110111.

\section{How to cite this article:}

Vinod Kumar, R.S. Mehta, S.S. Meena, Mahendra Parsoya, Rajveer and Chokh Nath Sidh. 2018. Study on Coriander (Coriandarum sativum L.)Based Intercropping System for Enhancing System Productivity. Int.J.Curr.Microbiol.App.Sci. 7(06): 3509-3514.

doi: https://doi.org/10.20546/ijcmas.2018.706.411 